\title{
Sophie White
}

Wild Frenchmen and Frenchified Indians: Material Culture and Race in Colonial

Louisiana. Philadelphia: University of Pennsylvania Press, 2012. Pp. 384. Hb, \$45.oo.

Until recently, the peripheral status of Louisiana in the greater French colonial empire translated into a rather understudied historiographical niche, with historians paying much more attention to French possessions in Canada and the Caribbean. Sophie White's Wild Frenchmen and Frenchified Indians joins the work of historians like Shannon Lee Dawdy, Lawrence Powell, Jennifer Spears, and Emily Clark in situating Louisiana within the wider world of colonial developments in early modern America and Europe. Specifically, White attends to the evolution of material culture and race in the daily lives of natives and newcomers throughout the Mississippi Valley from the Illinois Country to New Orleans. In this impressively researched book, White demonstrates, without a shadow of a doubt, that the cultural collision of Native Americans, Europeans, and Africans in French Louisiana is a subject that demands the attention of scholars interested in the history of Jesuit missionaries in the Americas. That being said, Jesuits are not the main characters in the book. Rather, White embeds the thoughts and actions of Jesuits within a web of cultural encounters mediated by men and women with European, Indian, and mixed ethnic backgrounds. She is also careful to distinguish between the experiences of the laity and clergy in Upper Louisiana (Illinois Country), Lower Louisiana (New Orleans), and the hinterlands between these two poles of missionary attraction. The result is a heightened respect for the everyday complicity of Jesuits in three interrelated activities - conversion, intermarriage, and Frenchificationthat White explores through the prisms of material culture and race.

Part one concentrates on the process of Frenchification in the Illinois Country. Frenchification, or la francisation, was the official intent of metropolitan and colonial officials to turn Indians into French subjects of the king. Premised on the malleability of identity, Indians exhibited distinctively French traits in the way they participated in Catholic sacraments, assumed French clothing practices, and married French settlers. Marie Rouensa-second in fame to only Catherine Tekakwitha as a Catholic convert in New France-is White's key example of how immersed many Indian women were in the French material culture of the Illinois Country. Chapter one, "Their Manner of Living," focuses on the physical and material appearance of Indian wives and daughters of Frenchmen. Chapter two, "Nothing of the Sauvage," and chapter three, "One People and One God," reiterate the point that conversion and intermarriage convinced many Frenchmen (including Jesuits) in Upper Louisiana of the effectiveness of the Frenchification policy. 
Part two extends the book's purview to Lower Louisiana, where colonial officials started to question the Frenchficiation strategy in favor of a more rigid differentiation between Europeans and Indians according to race. Chapter four, "The First Creole from This Colony That We Have Received," describes the limits of Frenchification in the person of Marie Turpin, the daughter of an Illinois convert mother and French father who entered the Ursuline convent in New Orleans as a converse (lay or domestic) nun in the mid-eighteenth century. Chapter five, "To Ensure That He Not Give Himself Over to the Sauvages," and Chapter six, "We Are All Sauvages," serves as a comparison between French-Indian and French voyageurs in the hinterlands between the Illinois Country and New Orleans. It was in this spatial threshold that voyageurs of both ethnic backgrounds demonstrated the tension between upholding French standards of dress and manner while simultaneously recognizing the utilitarian value of Indian modes of decorum. Since "birth was not the primary means of distinguishing French from Indian" in Upper Louisiana, White concludes that openness to the Frenchification of people of Indian descent "slowed the spread of racialization" in colonial Louisiana (232). The institution of the Code Noir in 1724 and the rise of African slavery in Lower Louisiana, however, worked as quickening agents in the ultimate rise of race-centered notions of identity throughout the Mississippi Valley. Jesuits, throughout the seventeenth and eighteenth centuries, played a critical role in defining and even encouraging a fluid moral understanding of ethnic and racial identity in colonial society.

Chief among the many merits of this volume is White's analysis of material culture in the identity politics of Native Americans and Europeans in French Louisiana. White proves that ideas about race and ethnicity were made manifest on the bodies and in the manners of people living in highly malleable colonial contexts. White's argument for the slowed process of racialization is all the more convincing because of her innovative interpretation of archival sources. To be blunt, the research that went into the writing of this book is simply incredible. Wild Frenchmen and Frenchified Indians marks a turning point in the burgeoning study of New France and is a model for scholars committed to understanding the history of early America.

\footnotetext{
Michael Pasquier

Louisiana State University

mpasquier@lsu.edu
} 